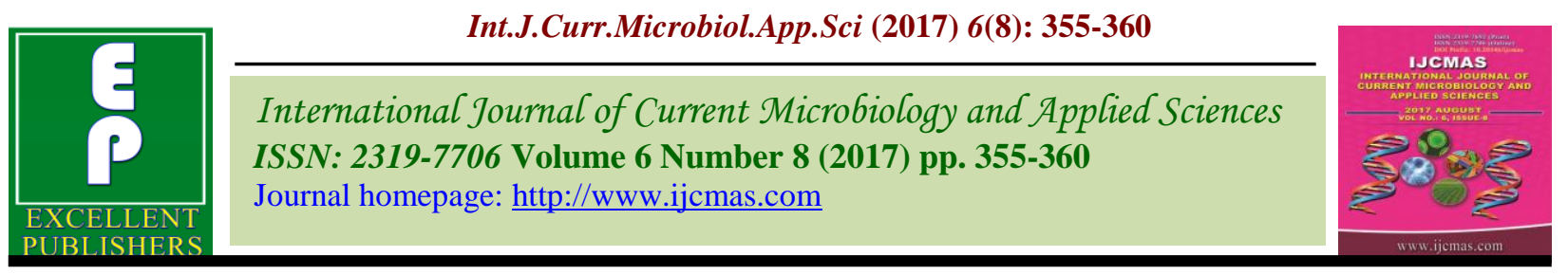

Original Research Article

https://doi.org/10.20546/ijcmas.2017.608.047

\title{
Generation Mean Analysis for Grain Yield and Its Contributing Traits in Pearl Millet [Pennisetum glaucum (L.)]
}

\author{
Gyanesh Kumar*, A.K. Singh, Deepak Barfa, D. Karthik, \\ Pawan Kumar and M.K. Kushwah
}

Department of Genetics and Plant Breeding, College of Agriculture, Rajmata Vijayaraje Scindia Krishi Vishva Vidyalaya, Gwalior, Madhya Pradesh - 474 002, India

*Corresponding author

\section{A B S T R A C T}

The experiment, consisting families $\left(\mathrm{P}_{1}, \mathrm{P}_{2}, \mathrm{~F}_{1}, \mathrm{~F}_{2}, \mathrm{BC}_{1}\right.$ and $\left.\mathrm{BC}_{2}\right)$ of 3 crosses of pearl millet viz., R-16419 × R-15114, R-15134 × R-15762, and R-15762 × ASRT-111. Joint

\begin{tabular}{|l|}
\hline Ke y w or d s \\
Joint scaling, \\
Gene effects, \\
Epistasis. \\
\hline Article Info \\
\hline Accepted: \\
04 June 2017 \\
Available Online: \\
10 August 2017 \\
\hline \hline
\end{tabular}
scaling test suggested that nodes per plant and days to physiological maturity were adequate for 3 parameter model. Six parameter models revealed that both additives (d) as well as additive $\times$ additive (i) type of gene effects were significant for seed setting in cross 'R-15134 × R-15762'. Duplicate type of epistasis was found for plant height, grain yield per plant in all three crosses of pearl millet, flag leaf length, 1000 seed weight in cross ' $R$ $16419 \times$ R-15114', tillers per plant, panicle length, seed setting, middle leaf temperature, harvest index in cross R-16419 $\times$ R-15114 and tillers per plant, panicle length, flag leaf length, middle leaf temperature, 1000 seed weight in cross of R-15762 $\times$ ASRT-111. Significant role of epistasis revealed that both additive as well non-additive effects involved in the expression of yield and its attributes, thus, reciprocal recurrent selection would be an ideal method for population improvement. Situation like duplicate type of gene action, breeding procedures involving multiple crosses, bi-parental crosses may be restored to get transgressive segregates.

\section{Introduction}

Pearl millet [Pennisetum glaucum (L.)] belongs to family poaceae and it is diploid $(2 n=2 x=14)$ with a large genome (2450 Mbp). It is a highly cross-pollinated with protogynous nature leads to high out crossing rate ranging between 70 to $80 \%$ (Burton, 1974), making the population structure of this crop highly heterozygous and heterogeneous. Pearl millet is a principal source of energy, protein, vitamins and minerals for millions of poorest people in the regions where it is cultivated. Pearl millet accounts about 50\% of the total global millet production and the West and Central Africa (WCA) region has large areas under millets (15.7 million hectares), of which more than $90 \%$ is pearl millet. During the period (2013-14) pearl millet occupied an area of $7.91 \mathrm{~m}$ ha with production of 9.19 million tons and productivity of $1161 \mathrm{~kg} / \mathrm{ha}$ (DES-DAC, 2014). The main purpose of pearl millet breeding is to increase grain yield. However, yield is a very complex character which is governed by polygene and affects many genetic and non-genetic factors, therefore, the knowledge about nature of gene action is essential to increase the efficiency of selection. Generation mean analysis provides 
information on the relative importance of additive, dominance and non-allelic genetic interactions such as additive $\times$ additive (aa), dominance $\times$ dominance $(\mathrm{dd})$ and additive $\times$ dominance (ad) effects to determining genotypic values of the individuals. Such analysis is very useful for rapidly obtaining the overall information on the various genetic system involving and for fixing selection indices for speedy gains in segregating generations.

\section{Materials and Methods}

The experimental material comprised of six basic generations viz., $\mathrm{P}_{1}, \mathrm{P}_{2}, \mathrm{~F}_{1}, \mathrm{~F}_{2}, \mathrm{BC}_{1}$ and $\mathrm{BC}_{2}$ derived from three set of crosses (R$16419 \times \mathrm{R}-15114, \mathrm{R}-15134 \times \mathrm{R}-15762, \mathrm{R}-$ $15762 \times$ ASRT-111) involving five genotypes of pearl millet. The six generations of above three set of crosses was raised in a complete randomized blocks design at College of Agriculture, Gwalior during kharif-2015. Each plot consisted $4 \mathrm{~m}$ long, single row of $\mathrm{P}_{1}, \mathrm{P}_{2}$ and $\mathrm{F}_{1} ; 2$ rows of $\mathrm{BC}_{1}$ and $\mathrm{BC}_{2}$ and 5 rows of $F_{2}$ with plant spacing of $50 \times 15 \mathrm{~cm}$. Observation were recorded on randomly selected 5 plants in each plot of $\mathrm{P} 1, \mathrm{P}_{2}$ and $\mathrm{F}_{1}$; 15 plants in $\mathrm{BC}_{1}$ and $\mathrm{BC}_{2}$ and 40 plants in $\mathrm{F}_{2}$ generations for 12 yield and components characters. The data were subjected to joint scaling test to detect gene effects and to test adequacy of 3 parameter model and six parameter models including non-allelic interaction (Cavalli, 1952). Six parameter models were fitted to estimate six gene effects parameters (Hayman and Mather, 1949).

\section{Results and Discussion}

The analysis of variance for grain yield per plant and its contributing traits revealed that the mean squares due to genotypes were significant for all the traits (Table 1). Estimation of $\chi^{2}$ of joint scaling reveled that six parameter model was found adequate for all yield and its attributing traits in all three crosses ('R-16419 × R-15114, R-15134 × R15762 and R-15762 × ASRT-111') except nodes per plant and days to physiological maturity in the cross of R-15762 X ASRT111.Estimate of gene effects (Table 2) revealed that mean effects (m) were significant for all traits in three set of crosses.

Additive gene effects (d) were significant for number of tiller per plant, panicle length, seed setting, middle leaf temperature at 60 DAS, harvest index in positive direction, Whereas, dominance (h) effects were significant for flag leaf length, days to $50 \%$ flowering, grain yield per plant, and 1000 seed weight in positive direction and plant height showed significant dominance (h) effects but in negative direction. The additive $\times$ additive (i) epistasis effect was significant for flag leaf length, days to $50 \%$ flowering, days to physiological maturity, grain yield per plant and 1000 seed weight in positive direction and plant height in negative direction.

Additive $\times$ Dominance $(j)$ effects were positive and significant for tiller per plant, panicle length, seed setting and harvest index but plant height showed significant in negative direction. The dominance $x$ dominance (l) interaction effect was positive and significant for plant height, whereas, significant but negative magnitudes for flag leaf length, days to physiological maturity, grain yield per plant and 1000 seed weight. In all significant characters(plant height, flag leaf length, grain yield per plant and 1000 seed weight) dominance (h) and dominance $x$ dominance (l) gene effects showed in opposite direction thereby it indicated duplicate type of non-allelic interaction for these traits.

On the basis of significant estimates of gene effects above result suggested that all the traits predominantly under the control of non- 
additive gene action in the cross of R-16419 $\times$ $\mathrm{R}-15114$. This is in conformity with earlier published reports such as Singh et al., (2017); Jog et al., (2016); Godasara et al., (2010); Singh et al., (2000).

In the cross $\mathrm{R}-15134 \times \mathrm{R}-15762$, additive effects (d) were positive significant for plant height, days to physiological maturity and panicle length, seed setting, flag leaf length in negative direction. The dominance gene effect (h) recorded positive and significant magnitudes for plant height, panicle length, flag leaf length, grain yield per plant and harvest index, tiller per plant, seed setting, and middle leaf temperature in negative direction.

The additive $\times$ additive (i) interaction effect was significant for panicle length, flag leaf length and harvest index in positive direction and tiller per plant seed setting, node per plant, middle leaf temperature in negative direction. Additive $\times$ Dominance (j) interaction effects were significant for tiller per plant, days to $50 \%$ flowering and days to physiological maturity in positive direction and panicle length and seed setting in negative direction. The dominance $\times$ dominance (l) interaction effect was significant for tiller per plant, middle leaf temperature and seed setting in positive direction, whereas, plant height, panicle length, grain yield per plant showed significant negative magnitudes of dominance $\times$ dominance (l) interaction. Additive (d), additive $\times$ additive (i) type of gene effect were recorded for panicle length, flag leaf length in opposite direction which revealed that cancelling the magnitude of fixable type of gene action of these traits. Whereas seed setting showed in same but in negative direction which revealed magnitude boosting of fixable type of gene action. Dominance (h) and dominance $\times$ dominance (1) showed magnitudes in opposite direction for most of characters (plant height, tiller per plant, seed setting, node per plant, flag leaf length, middle leaf temperature, days to $50 \%$ flowering, grain yield per plant and harvest index), thereby, indicating duplicate type of non-allelic interaction. Hence on the basis of significant estimate of gene effect above result suggested that all the traits predominantly under the control of nonadditive gene effects. These finding results shows conformity with previous published reports such as Singh et al., (2017), Jog et al., (2016), Godasara et al.,(2010), Singh et al., (2000).

In case of cross R-15762 × ASRT-111, none of the character showed significant additive effect. The dominance gene effect (h) recorded significant for plant height, tiller per plant, panicle length, seed setting, flag leaf length, middle leaf temperature, grain yield per plant, harvest index and 1000 seed weight in positive direction.

The additive $\times$ additive (i) interaction effect was significant for tiller per plant, panicle length middle leaf temperature, harvest index and 1000 seed weight in positive direction. The Additive $\times$ Dominance $(j)$ interaction effect was significant for seed setting. The dominance $\times$ dominance (l) interaction effect was negative and significant for plant height, tiller per plant, panicle length, flag leaf length, middle leaf temperature, grain yield per plant and 1000 seed weight. In most of the characters (plant height, tiller per plant, panicle length, seed setting, flag leaf length, middle leaf temperature, grain yield per plant harvest index and 1000 seed weight) dominance $(\mathrm{h})$ and dominance $\times$ dominance (l) showed in opposite direction, thereby, it indicated duplicate type of non-allelic interaction. These finding results obtained similar trends by Singh et al., (2017) Jog et al., (2016) Godasara et al., (2010) Singh et al., (2000). 
Table.1 Analysis of variance for yield and its attributing traits in three sets of crosses viz., R-16419 X R-15114, R-15134 X R-15762,

\begin{tabular}{|c|c|c|c|c|c|c|c|c|c|c|c|c|c|}
\hline Source & d.f. & $\begin{array}{l}\text { Plant } \\
\text { Height } \\
(\mathrm{cm})\end{array}$ & $\begin{array}{l}\text { No of } \\
\text { Tillers } \\
\text { /Plant }\end{array}$ & $\begin{array}{l}\text { Panicle } \\
\text { length } \\
(\mathrm{cm})\end{array}$ & $\begin{array}{c}\text { Seed } \\
\text { Setting } \\
(\%)\end{array}$ & $\begin{array}{c}\text { Nodes / } \\
\text { plant }\end{array}$ & $\begin{array}{l}\text { Flag leaf } \\
\text { length } \\
(\mathrm{cm})\end{array}$ & $\begin{array}{c}\text { Middle Leaf } \\
\text { Temp. at } 60 \\
\text { DAS }\end{array}$ & $\begin{array}{c}\text { Days to } \\
50 \% \\
\text { Flowering } \\
\end{array}$ & $\begin{array}{c}\text { Days To } \\
\text { physiological } \\
\text { maturity }\end{array}$ & $\begin{array}{c}\text { Grain } \\
\text { yield / } \\
\text { plant (g) }\end{array}$ & $\begin{array}{c}\text { Harvest } \\
\text { index } \\
(\%)\end{array}$ & $\begin{array}{l}1000 \text { seed } \\
\text { weight }(\mathrm{g})\end{array}$ \\
\hline Replication & 2 & 3.742 & 0.002 & 0.466 & 1.566 & 0.113 & 2.905 & 0.065 & 0.817 & 0.957 & 0.479 & 1.760 & 0.104 \\
\hline Genotypes & 17 & $358.568 * *$ & $0.214 * *$ & $21.329 * *$ & $49.627 * *$ & $0.693 * *$ & $17.268 * *$ & $1.184 *$ & $3.623 *$ & $0.927^{*}$ & $4.238 * *$ & $48.138 * *$ & $0.360 * *$ \\
\hline Error & 34 & 17.188 & 0.032 & 1.474 & 9.329 & 0.184 & 6.104 & 0.524 & 2.302 & 0.676 & 0.568 & 5.549 & 0.042 \\
\hline
\end{tabular}

*and $* *$ significant at $5 \%$ and $1 \%$ levels of significance respectively

Table.2 Gene effect analysis for grain yield and its attributes in three sets of crosses viz., R-16419 X R-15114, R-15134 X R-15762, R-15762 X ASRT-111

\begin{tabular}{|c|c|c|c|c|c|c|c|c|c|c|c|c|}
\hline Scale effect & $\begin{array}{l}\text { Plant } \\
\text { height } \\
(\mathrm{cm})\end{array}$ & $\begin{array}{c}\text { tillers / } \\
\text { plant }\end{array}$ & $\begin{array}{c}\text { Panicle } \\
\text { length }(\mathrm{cm})\end{array}$ & $\begin{array}{c}\text { Seed } \\
\text { setting } \\
(\%)\end{array}$ & $\begin{array}{c}\text { nodes / } \\
\text { plant }\end{array}$ & $\begin{array}{c}\text { Flag leaf } \\
\text { length } \\
(\mathrm{cm})\end{array}$ & $\begin{array}{l}\text { Middle leaf } \\
\text { temp. at } 60 \\
\text { DAS }\end{array}$ & $\begin{array}{c}\text { days to } \\
50 \% \\
\text { flowering } \\
\end{array}$ & $\begin{array}{c}\text { Days to } \\
\text { physiological } \\
\text { maturity }\end{array}$ & $\begin{array}{c}\text { Grain } \\
\text { yield / } \\
\text { plant (g) }\end{array}$ & $\begin{array}{c}\text { Harvest } \\
\text { index }(\%)\end{array}$ & $\begin{array}{l}\text { 1000Seed } \\
\text { weight }(\mathrm{g})\end{array}$ \\
\hline \multicolumn{13}{|c|}{ R-16419*R-15114 } \\
\hline $\mathrm{m}$ & $178.17 * *$ & $2.00 * *$ & $25.30 * *$ & $94.70 * *$ & $8.17 * *$ & $47.97 * *$ & $31.98 * *$ & $48.53 * *$ & $77.60 * *$ & $19.26 * *$ & $26.23 * *$ & $1.04 * *$ \\
\hline $\mathrm{d}$ & -2.13 & $0.33 * *$ & $2.87 * *$ & $4.80 * *$ & 0.07 & 2.99 & $1.23 * *$ & 0.87 & -0.10 & 0.67 & $7.34 * *$ & 0.02 \\
\hline $\mathrm{h}$ & $-17.43 * *$ & -0.60 & -4.43 & 2.63 & -0.27 & $13.48 * *$ & 1.33 & $10.37 * *$ & 4.29 & $10.44 * *$ & -5.96 & $2.95 * *$ \\
\hline $\mathrm{i}$ & $-21.73 * *$ & -0.40 & -6.13 & -0.40 & 0.27 & $13.84 * *$ & 1.41 & $8.13 * *$ & $5.27 * *$ & $8.67 * *$ & -6.12 & $2.59 * *$ \\
\hline $\mathrm{j}$ & $-6.70 * *$ & $0.53 * *$ & $6.30 * *$ & $9.10 * *$ & -0.27 & 3.22 & 1.07 & 0.90 & 0.35 & 0.47 & $6.23 * *$ & -0.04 \\
\hline 1 & $33.13 * *$ & -1.20 & -7.80 & -5.13 & -2.53 & $-21.14 * *$ & 0.46 & -8.20 & $-9.64 * *$ & $-12.71 * *$ & $37.07 * *$ & $-1.26 * *$ \\
\hline \multicolumn{13}{|c|}{ R-15134*R-15762 } \\
\hline $\mathrm{m}$ & $175.43 * *$ & $2.00 * *$ & $20.60 * *$ & $94.33 * *$ & $7.57 * *$ & $49.69 * *$ & $33.49 * *$ & $48.80 * *$ & $78.73 * *$ & 20.47 & $29.37 * *$ & $1.24 * *$ \\
\hline $\mathrm{d}$ & $4.87 *$ & -0.07 & $-2.87 * *$ & $-9.40 * *$ & -0.27 & $-3.71 * *$ & 1.35 & 2.48 & $1.27 * *$ & 0.17 & 2.21 & 0.28 \\
\hline $\mathrm{h}$ & $32.67 * *$ & $-2.22 * *$ & $10.26 * *$ & $-25.10 * *$ & -1.80 & $9.20 * *$ & $-5.88 * *$ & 3.21 & -1.33 & $9.43 * *$ & $15.65 * *$ & 2.14 \\
\hline $\mathrm{i}$ & -1.07 & $-2.27 * *$ & $8.40 * *$ & $-27.60 * *$ & $-2.27 * *$ & $8.17 * *$ & $-5.94 * *$ & 4.68 & -1.47 & 6.39 & $15.52 * *$ & 1.70 \\
\hline $\mathrm{j}$ & 4.60 & $0.32 *$ & $-3.34 * *$ & $-8.83 * *$ & -0.15 & -1.40 & 1.51 & $3.87 * *$ & $1.73 * *$ & 0.04 & 1.32 & 0.25 \\
\hline 1 & $-42.80 * *$ & $2.83 * *$ & $-9.32 * *$ & $43.27 * *$ & 2.33 & -7.67 & $7.78 * *$ & -9.05 & 0.53 & $-11.05^{* *}$ & $-17.43 * *$ & -0.55 \\
\hline \multicolumn{5}{|c|}{ R-15762*ASRT-111 } & \multicolumn{4}{|l|}{ TPM } & \multicolumn{4}{|l|}{ TPM } \\
\hline $\mathrm{m}$ & $168.10^{* *}$ & $1.40 * *$ & $24.70 * *$ & $96.10 * *$ & $7.36 * *$ & $52.00 * *$ & $31.43 * *$ & $50.11 * *$ & $78.34 * *$ & $20.93 * *$ & $28.28 * *$ & $1.00 * *$ \\
\hline $\mathrm{d}$ & -1.47 & -0.20 & 2.03 & -1.13 & 0.07 & 3.49 & 0.05 & -0.23 & -0.04 & -0.64 & 1.29 & 0.13 \\
\hline $\mathrm{h}$ & $37.03 * *$ & $1.40 * *$ & $11.50 * *$ & $4.87 * *$ & 0.16 & $17.45 * *$ & $4.43 * *$ & -0.78 & $0.87 * *$ & $6.39 * *$ & $14.65 * *$ & $3.33 * *$ \\
\hline $\mathrm{i}$ & 15.60 & $1.47 * *$ & $9.13 * *$ & -0.27 & - & 11.91 & $5.78 * *$ & -0.49 & - & 3.97 & $16.39 * *$ & $2.81 * *$ \\
\hline $\mathrm{j}$ & -1.10 & -0.23 & 1.07 & $3.67 * *$ & - & 2.83 & 0.34 & 0.80 & - & -0.29 & 2.93 & 0.03 \\
\hline 1 & $-34.20 * *$ & $-2.80 * *$ & $-25.80 * *$ & -6.67 & - & $-23.58 * *$ & $-7.82 * *$ & -2.27 & - & $-7.88 *$ & -0.17 & $-1.62 * *$ \\
\hline
\end{tabular}

*and $* *$ significant at $5 \%$ and $1 \%$ levels of significance respectively, TPM: Three parameter model 
In this cross, estimate of gene effect suggested that all these traits predominantly under the control of non-additive gene effects. Since, six -parameter models was inadequate for node per plant and days to physiological maturity, three parameters reveled that for days to physiological maturity dominance (d) gene effect was significant. Hence on the basis of significant estimate of gene effects above result suggested that days to physiological maturity predominantly under the control of non-additive gene effects. These finding results obtained by Jog et al., (2016) were reported earlier similar trends for day to maturity in cross ICMB-20071 x J2480 and ICMB-04999 x J-2454 respectively.

In conclusion, the findings of this investigation demonstrated that cross (R15134 X R-15762) fixable components of gene effect (additive, additive $\mathrm{x}$ additive) were observed important in the inheritance for panicle length and flag leaf length in opposite direction which revealed that cancelling the magnitude of fixable type of gene action of these traits. Dominance gene effect and dominance $\mathrm{x}$ dominance type of epistasis played vital role for grain yield per plant, plant height in three crosses viz., (R-16419 X R-15114, R-15134 X R-15762, R-15762 X ASRT-111), flag leaf length, 1000 seed weight in two crosses viz., (R-16419 X R15114, R-15762 X ASRT-111) and tillers per plant, panicle length and middle leaf temperature in two crosses viz., (R-15134 X $\mathrm{R}-15762$, R-15762 X ASRT-111). In traits like seed setting, harvest index in cross R15134 X R-15762 also played vital role of dominance gene effect and dominance $x$ dominance type of epistasis. In case of yield contributing characters, the role of both additive and non-additive components were prevalent for most of traits. Significant role of epistasis revealed that additive as well nonadditive effects are involved in the expression of yield and its attributes, thus, a breeding scheme efficient in exploiting both type of gene effects should be employed. Reciprocal recurrent selection would be an ideal method. Under a situation like duplicate type of gene action, breeding procedures involving multiple crosses, bi-parental crosses may be restored to get transgressive sergeants. The additive gene effects may be exploited by fixing these traits through selection method of plant breeding, while non-additive gene effects may be exploited by using cyclic method of breeding involving selection and hybridization of desirable sergeants from concerned crosses.

\section{References}

Burton, G., W. 1974. Factors affecting pollen movement and natural crossing in pearl millet. Crop Science, 14: 802-805.

Cavalli, L., L. 1952. An analysis of linkage in quantitative inheritance in Quantitative Inheritance, (Rieve, ECR and Waddington, C. H Ed) HMSO London, pp135.

DES-DAC. 2014. Department of Agriculture and Cooperation, Ministry of Agriculture, Government of India, available at http://www.agricoop.nic.in.

Godasara, S., B. Dangaria, C. J. Savaliya, J.J. Pansuriya, A.G. and Davada, B.K. 2010. Generation mean analysis in pearl millet [Penisetum glaucum (1.) R. Br.]. Agricultural Science Digest. 30 (1): 5053.

Jog, K., H. Kachhadia, V. H. Vachhani, J. H. and Lalwani, H. H. 2016.Generation mean analysis and inbreeding depression in pearl millet [Pennisetum glaucum (L.) R. Br.]. Electronic Journal of Plant Breeding. 7(3): 469481.

Mather, K., 1949. Biometrical Genetics, 1st Edn. Dover Publications. Inc., New York.

Singh, A., Singh, B. and Singh, R. 2017. 
Genetic Analysis of Yield and Yield Component Traits in Three Crosses of Pennisetum typhoides in India. Ekin Journal of Crop Breeding and Genetics. 3(1):72-82.
Singh, B., Govila, O. P. and Sheoran, R.K. 2000.Generation mean analysis for yield components in pearl millet. Annals of Agricultural Research. 21(1): 23-26.

\section{How to cite this article:}

Gyanesh Kumar, A.K. Singh, Deepak Barfa, D. Karthik, Pawan Kumar and Kushwah M.K. 2017. Generation Mean Analysis for Grain Yield and Its Contributing Traits in Pearl Millet [Pennisetum glaucum (L.)]. Int.J.Curr.Microbiol.App.Sci. 6(8): 355-360. doi: https://doi.org/10.20546/ijcmas.2017.608.047 